\title{
WASTE UTILIZATION TRAINING ABOUT STYROFOAM BECOME A BATAKO IN THE SCAVENGER WASTE COMMUNITY IN PALOPO CITY
}

\author{
Indra Amanah ${ }^{1}$, Miftahul Jannah ${ }^{2,}$ Ishak $^{3}$ \\ ${ }^{1,2,3}$ Faculty of Health , Mega Buana Palopo University
}

Corresponding Author : Indra Amanah

Email : : indra.amanah.andinurhayati@gmail.com

\section{Abstract}

Background: The amount of waste that is not processed and classified as non-biodegradable waste such as Styrofoam, well managed household waste is $36.8 \%$. The amount of waste that is not properly managed is $63.2 \%$ of the total weighted waste of 282,654 tonnes. Lack of training for scavengers and the community has resulted in a large amount of stytrofoam waste not being used.

Methods: The purpose of this study was to assess the effect of training on using Styrofoam waste into bataco. This research is a pre-experimental study with a one group pre testpost test design, conducted a pretest, then given treatment in the form of training and practice recycling styrofoam into concrete blocks. After that, within a period of approximately 1 month after treatment, a posttest is carried out to measure again. The respondents were trash scavengers, amounting to 83 people.

Results: The test results in this study indicate that there is an effect of training on the use of Styrofoam waste into concrete blocks in the garbage scavenger community in Palopo City with a value of $\mathrm{p}=0.000$.

Conclusion: Styrofoam can be modified to become concrete clocks. This can reduce the garbage waste in the community in Palopo City.

Keywords: Training, Styrofoam, Scavengers, Garbage 


\section{INTRODUCTION}

Total volume of garbage in South Sulawesi, every day reached 1000 tons / day, bins were not treated reached 425 tons / day. Figures this will continueto increase ev ery year, given that the population of Indonesia more years will continue to grow and will affect large to increase the volumeof garbage, especially garbage inorga nic (Ministry of Environment and Forestry, 2018; the Environment Agency, 2018) Managementof garbage house househ old in South Sulawesi which is managed by the well of $35.8 \%$ and whichis not managed by the well amounted to $64.2 \%$ of the amount of garbage that is weighted as much as 8,677 tons (Ministry of Health of the Republic of Indonesia, 2018) . 3R behavior (Reuse,

Reduce, Recycle) is still rarely done. The percentage of themost frequently treated garbage to the $r$ ecycling reset to $0.19 \%$, making manure com post $0.53 \%$, is used for food animal $0.26 \%$, still less than 1 $\%$. While approximately $54.65 \%$ house stairs most often dispose of garbage by means burnt (Health, 2018). Penglolaan garbage home household who managed with good by $36.8 \%$ and the amount of garbage that is not managed by either of $63.2 \%$ of the amount of garbage that is weighted as much as 282.654 tons (Ministry of Environment and Forestry, 2018; Sucipto, C, 2012)

A large amount of trash that is thrown away every day shows that in every day soci ety produce bins with the number of the lot. The amount of garbage that is generated and is not managed by the well can cause pollution . Contamination occurs when people who used

to burn garbage, and throw trash any place su ch as a river or the gardens empty and hoarding rubbish which $\mathrm{i}$ $\mathrm{s}$ difficult to unravel as Styrofoam (Abida, 2017; Sumantri, 2015). To overcome the problem that, it is necessary to do an effort to improve the knowledge, self efficacay and skills the recycle birthday or utilize

the back of garbage into a material that is useful as a form of concern about the environment and health. As well as the research that is carried out showed that the factor education in terms of this training , a factor that is most holding role important in the sustainability of the craft based garbage in the hamlet Sukunan (Atmaji， 2017; Wirahadi, 2016). As is in the study is based on the results

of interviews with respondents who are scav engers declare that they at all have not been given the

training associated with the use of garbage styrofoam, so not yet know how, moreover to practice cultivation or use was at once yet had an idea. It is also the underlying research to provide treatment in the form of training of the utilization of waste styrofoam on a scavenger of garbage in City Palopo .

\section{METHOD}

Research is a research pre experiment with the design of one group pretest posttest design (Creswell, 2016) done pretest, then given a treatment in the form of training and practice of recycling the Styrofoam into a brick. After that in the period of time less over 1 month after treatment carrie $\mathrm{d}$ out post-test to measure the return of selfefficacy, knowledge and skills of the utilization of waste Styrofoam into a brick. The number of respondents in this study were 83 scavengers. The data obtained in this study were analyzed usi ng the Wilcoxon test. 


\section{RESULTS AND DISCUSSION}

Table 1. Distribution of respondents based on gender

type gender Frequency (f) Percentage

(\%)

\begin{tabular}{|c|c|c|}
\hline Male & 28 & 33.73 \\
\hline Women & 55 & 66.27 \\
\hline Total & 83 & 100 \\
\hline
\end{tabular}

Source : Primary data, 2020

In table 1 show of

the 83 respondents, the distribution of types of sex male number 28

$(33.73 \%)$

of scavengers and the manifold sex women a s much as $55(66.27 \%)$ of scavengers .

Table 2. Effect

of training

on the use of styrofoam waste .

\begin{tabular}{lccc}
\hline & Mean & SD & $\begin{array}{c}p \text { - } \\
\text { value }\end{array}$ \\
\hline Pretest & 20.59 & 5.25 & 0,000 \\
Posttest & 34.98 & 0.15 & \\
\hline Note: Wilcoxon test & &
\end{tabular}

Note : Wilcoxon test

Based on table 2, from

the results of the Wilcoxon test analysis , the mean pretest $=$ 20.59 and posttest $=$ 34.98 and the pretest and posttest $p$ values ar e 0.000 or less than 0.05 . In the study it was also obtained that before given training of sc avengers at once has not been able to practice the way of processing garbage Styrofoam, but once give $\mathrm{n}$ the

training they are skilled to practice to produc e work thatis worth economical form of bricks from waste Styrofoam. It is demons trated that the difference in value of the average

/mean between pretest to posttest . Results of the study is also in line with research that has been done by Kurniaty\& Rizal ( 2011) on the utilization of the results of the management of garbage as an alternative material of building construction. In addition it is also no research that has the effect that the research that is done by Marliani ( 2015) concerning the usof waste home household (garbage anrorga nik) as a form of implementation of the educational environment.

\section{CONCLUSIONS}

There is the effect of the training on the use of waste Styrofoam into

a brick on scavenger of garbage in City Palopo . This study suggests:

1. The environmental office can adapt $t$ his training to be applied to other groups of scavengers.

2. The Government through the office environment life that overs hadowed the field of hygiene needs to be much socializing related to the utilization

of waste Styrofoam and establish coo peration with the private consumer re sults of the work of the scavenger as a step minimize trash that is not processed.

\section{REFERENCES}

1. Abida, H. N. (2017). Model of Environmental Empowerment and Community Economic Empowerment through Recycling of Waste in Sukunan Environmental Tourism Village. Social Studies, 6(6), 654-667.

2. Atmaji, L. T. (2017). Management of Waste Empowerment Based Crafts Businesses in Sukunan Hamlet, Banyuraden Village, Sleman Regency. Jurnal Tata Kelola Seni, 2(2), 1-6. https://doi.org/10.24821/jtks.v2i2.1818

3. Creswell, J. W. (2016). Research 
Design, Qualitative, Quantitative, and Mixed Methods Approaches. 368.

4. Dewi, P. K. (2017). Empowering Woman through the Plastic Waste Recycling Program at the Kartini Independent Waste Management Group, Radungunting Tamansari Kalasan, Sleman. Universitas Negeri Yogyakarta.

5. Environmental Services. (2018). Annual Program Profile. Palopo.

6. Faizah. (2008). Community Based Housedhold Waste Management 1-154.

7. Ministry of Health of the Republic of Indonesia. (2018). Riskesda. Jakarta.

8. Ministry of Environment and Forestry, Republic of Indonesia. (2018). National Waste Management Information System. Retrieved from http://sipsn.menlhk.go.id/?q=3a-dataumum

9. Ministry of Health of the Republic of Indonesia(2018). Main Result of Basic Health Research. Ministry of Health of the Republic of Indonesia, 1-100. https://doi.org/1 Desember 2013

10. Kurniaty, D. R., \& Rizal, M. (2011). e- ISSN: $\mathbf{2 7 1 5 - 4 7 1 8}$

Utilization of Waste Management Result as Alternative Construction Building Materials. Jurnal Smartek, 9(1), 47-60.

11. Marliani, N. (2015). Utilization of Household Waste (Inorganic Waste) as a Form of Implementation of Enfironmental Education. Formatif: Jurnal Ilmiah Pendidikan MIPA, 4(2), 124-132.

https://doi.org/10.30998/formatif.v4i2.1 46

12. Purwaningrum, P. (2016). Effort to Reduce the Generation of Plastic Waste in the Environment. 8(2), 141-147.

13. Santoso, A., \& Widodo, S. (2011). Utilization of Styrofoam Waste ( Expanded Polysterene) For Wall Making. $\quad \operatorname{VII}(1), \quad 1-18$. https://doi.org/10.1109/ICCV.2013.269

14. Sucipto, C, D. (2012). Waste Processing and Recycling Technology. Yogyakarta: Nuha Medika.

15. Sumantri. (2015). Environmental Health. Jakarta: Kencana.

16. Wirahadi, M. (2016). Interior Elements Made of Raw Styrofoam Waste and Orange Peel Waste.None, 5(2), 144-153. 